\title{
Cross breeding trials with Sheep-Effect of dam Factors
}

\author{
L. A. GOONEWARDENE
}

Department of Animal Science, University of Peradeniva, Peradeniya, Sri Lanka

AND

M. AGALAWATTE

Veterinary Research Institute, Gannoruvi, Sri Lanka

(Date of receipt: 26 May 1981)

(Date of acceptance: 6 March 1984)

\begin{abstract}
The data for this analysis was obtained from the Government livestock farm at Wirawila. The objectives of the study were to determine firstly, the performance of the Wiltshire Horn $\times$ Local (WL) sires crossed to Bikaneri (B) and Wiltshire Horn - Local $\times$ Bikaneri (WLB) ewes, based on the birth weight, 3 -month and 6 -month body weights of their cross bred progeny. Secondly, the effect of the breed of ewe, age of ewe, lambs' year of birth and sex of lamb on birth, 3 and 6 -month weight was analysed. Two analytical models were used for the purpose. The WL sires combined better with WLB ewes and their cross bred progeny were significantly heavier than the $\mathrm{WL} \times \mathrm{B}$ cross breds at all ages. One model showed that the breed of ewe, lambs' year of birth and sex of lamb had a significant effect on birth, 3 and 6 -month body weights. In the other model, breed of ewe was significant only for 3 and 6 -mónth weight while sex of lamb was significant at all ages.
\end{abstract}

\section{Introduction}

The improvement of the overall efficiency of mutton production must come by achieving higher reproductive rates among breeding stock and growth rates of lambs and young stock. By the use of selected breeds in cross breeding programs, increased efficiency could be partly achieved. Good management of the breeding and market stock will also help to improve performance and increase profits.

The objectives of the present study were to determine firstly, the performance of Wiltshire Horn - Local (WL) sires crossed to Bikaneri (B) ewes and Wiltshire Horn - Local Bikaneri (WLB) ewes, on the basis of their progeny body weights at birth, 3 months and 6 months. The second part of the study analysed the effects of factors such as breed of ewe, age of ewe, lamb's year of birth and sex of lamb on birth, 3-month and 6-month weights. Two models were assumed for the study, the first using all the lamb weight information during the years 1974 and 1976 (Model 1) and the second using information on the lambs born in 1976 (Model 2). 


\section{Materials and Methods}

The data for this analysis were obtained from the records of the Government livestock farm at Wirawila, during the years 1974 and 1976. The farm is situated in the south east region of Sri Lanka and receives an average annual rainfall of $109 \mathrm{~cm}$ and experiences a temperature of $27.2^{\circ} \mathrm{C}$. The rainfall is high during the Maha season (October to January) and pasture growth and availability is dependent on the rainfall.

During the years from about 1969 to 1973, a population of Wiltshire Horn $X$ Local sheep was established at Wirawila ${ }^{2}$ and from this population, rams were used to sire the ewes in this analysis. Similarly, Wiltshire Horn $x$ Local ewes were also available and these were bred to Bikaneri rams to produce a three breed cross WLB. These females were used for the study. Ewes were bred during July/August of the year by allowing the rams to run with the herds and lambing occurred from November of each year. A ratio of about 1 ram to 12 ewes was maintained.

Local sheep, also called Jaffna sheep which have hair rather than wool, range in colour patterns from black to white, weight approximately $1.9 \mathrm{~kg}$ at birth, $6.35 \mathrm{~kg}$ at 4 months of age and $18.14 \mathrm{~kg}$ at 1 year of age. ${ }^{10}$ Buvanendran ${ }^{2}$ estimated adult body weights for males and females at $23 \mathrm{~kg}$ and $18 \mathrm{~kg}$ respectively, and gave breed descriptions and body weights for Bikaneri, Wiltshire Horn and their crosses. ${ }^{2,8}$

The data used for the study in model 1 included 260 lambs of B and WLB ewes bred to WL rams. There were 78 lambs out of Bikaneri ewes crossed to WL sires in 1976 of which 51 lambs were from yearling ewes and 27 from 2-year olds. The rest of the sample consisted of 182 WL $\times$ WLB lambs in 1976, of which 36 were from yearling ewes, 74 from 2-year old ewes and 72 lambs from yearling ewes in 1974 . A part of the same data which included only the year 1976 was used for the analysis in model 2. This study included a total of 188 lambs of which 78 were out of $\mathrm{B}$ ewes and 110 out of WLB ewes crossed to WL sires.

The progeny of each cross was numbered, color tagged and maintained in one herd along with their mothers. No twins were used for the present study. All lambs were weaned at 3 months. The sheep were allowed to graze on an established field of Brachiaria brizantha during the day and housed in open sheds for the night where limited grazing was available. The availability and nutritive value of the pasture depended entirely on the rainfall and the prevailing farm practices. No concentrates were fed to the lambs. Water was provided for the sheep at noon each day and again in the evenings. The usual farm management practices were followed. 
The body weights of the young cross breds were recorded in $\mathrm{kg}$ at birth and then at monthly intervals up to 12 months. The body weights used for this analysis were those at birth, 3 months and 6 months.

In model 1, the sources of variation breed of ewe, age of ewe, year of birth were combined (BAY)* along with sex of lamb and their effect on birth, 3-month and 6-month weight was determined. BAY was put in with 4 degrees of freedom while sex was associated with a single degree of freedom. In model 2, the effect of the breed of ewe and sex of lamb on birth, 3-month and 6-month weight for one and two-year old ewes combined for the year 1976 was determined. A least squares program was used to derive least squares means, analysis of variance and simple correlations between the weights at different ages. ${ }^{9}$ A F-statistic was used to test the significance in each analysis of variance while a t-statistics tested whether the simple correlations were significantly different from zero, ${ }^{15}$

\section{Results and Discussions}

The analysis of variance for model 1 in which the variation was partitioned into Breed-Age-Year and sex of lamb is shown in Table 1, and the analysis of variance for model 2 is shown in Table 2.

Table 1. Analysis of variance for Model 1

\begin{tabular}{|c|c|c|c|c|}
\hline \multirow{2}{*}{$\begin{array}{l}\text { Source of } \\
\text { variation }\end{array}$} & \multirow[b]{2}{*}{$d f$} & \multicolumn{3}{|c|}{ Mean Squares } \\
\hline & & Birth weight & 3-month weight & 6 -month weight \\
\hline BAY & 4 & $7.97^{* * *}$ & $1261.29^{* *}$ & $1701.33^{* *}$ \\
\hline Sex & 1 & $6.07^{*}$ & $152.34^{* *}$ & $850.46^{* *}$ \\
\hline Residual & 254 & 1.05 & 15.74 & 17.41 \\
\hline
\end{tabular}

** $\mathrm{P}<0.01$

${ }^{*} \mathrm{P}<0.05$

Table 2. Analysis of variance for Model 2

\begin{tabular}{|c|c|c|c|c|}
\hline \multirow{2}{*}{$\begin{array}{l}\text { Source of } \\
\text { variation }\end{array}$} & \multirow[b]{2}{*}{$d f$} & \multicolumn{3}{|c|}{ Mean Squares } \\
\hline & & Birth weight & 3-month weight & 6-month weight \\
\hline Breed of ewe & 1 & 2.95 & $722.60^{* *}$ & $1622.36^{* *}$ \\
\hline Sex & 1 & $6.21 * *$ & $136.29 * *$ & $720.12^{* *}$ \\
\hline Residual & 185 & 1.14 & 18.50 & 27.33 \\
\hline
\end{tabular}

** $\mathrm{P}<0.01$

$* \mathrm{P}<0.05$

* Abbreviated for Breed-Age-Year. 
The sources of variation BAY had a highly significant effect on lamb birth weight, 3-month and 6-month weight (Table 1). In model 2 , breed of ram had no significant effect on birth weight but was significant for weight at 3 and 6 months of age. Daflapurkar ${ }^{5}$ reported significant breed of ewe effects for birth weight while, Farid $^{6}$ reported significance of this source of variation for birth and weaning weight. The significance of the age of ewe on birth and weaning weight was reported it among Corriedale sheep, white Farid ${ }^{6}$ recognised the age of ewe as being significant for birth weight only. Chang and Raes reported that the age of ewe accounted for 2.1 per cent of the total variation in weaning weight among Romney Marsh lambs in New Zealand. Significant year. of birth effects on birth and weaning have been reported in the literature supporting this analysis.10,14 Chang and Rae reported that the effect can account for $2.0 \%$ of the total variation in weaning weight, among Romney lambs. The sex of lamb was significant for all ages in the present study in models 1 and 2. Similar findings where male lambs were heavier than females have been reported $5,7,11,12,13$ among other sheep breeds.

Least squares means and standard errors for birth, 3-month and 6-month weight, by breed of ewe, age of ewe, lamb's year of birth and sex are shown in Table 3.

Table 3. Least squares means and standard errors for Model 1

\begin{tabular}{|c|c|c|c|c|c|c|c|}
\hline \multirow[b]{2}{*}{$\begin{array}{l}\text { Breed of } \\
\text { ewe }\end{array}$} & \multirow[b]{2}{*}{$\begin{array}{l}\text { Age of } \\
\text { ewe }\end{array}$} & \multirow[b]{2}{*}{$\begin{array}{l}\text { Lamb's lear } \\
\text { of Birth. }\end{array}$} & \multirow[b]{2}{*}{$\begin{array}{l}\text { Sex of } \\
\text { Lamb }\end{array}$} & \multirow{2}{*}{$n$} & \multicolumn{3}{|c|}{ Weight $(K g) \quad t_{-} S e$} \\
\hline & & & & & Birth & 3-month & 6-month \\
\hline B & 1 & 1976 & $M \& F$ & 51 & $2.96: 0.06$ & $11.40: 0.25$ & $16.24 \div 0.26$ \\
\hline B & 2 & 1976 & $M \& F$ & 27 & $3.20+0.09$ & $12.76,0.34$ & $19.54+0.36$ \\
\hline WLB & 1 & 1976 & $M \& F$ & 36 & $3.13+0.08$ & $12.88+0.29$ & $18.53 \pm 0.31$ \\
\hline WLB & 2 & 1976 & $M \& F$ & 74 & $3.32: 0.05$ & $14.46 \div 0.21$ & $21.10 \pm 0.22$ \\
\hline WLB & 1 & 1974 & $M \& F$ & 72 & $3.33: 0.05$ & $16.77 \quad 1.0 .21$ & $22.50 \times 0.22$ \\
\hline$B \& W L B$ & $1 \& 2$ & $1974 \& 76$ & $M$ & 133 & $3.27: 0.04$ & $14.00+0.16$ & $20.39: 0.17$ \\
\hline B \& WLB & $1 \& 2$ & $1974 \& 76$ & $\mathrm{~F}$ & 127 & $3.13 \div 0.04$ & $13.31: 0.16$ & $18.77 \cdot 0.17$ \\
\hline ....... & & & & & - & $\cdots$ & \\
\hline
\end{tabular}

The WL $\times$ WLB cross bred which contained approximately 37.5 per cent Wiltshire Horn, 31.5 per cent Local and 25 per cent Bikaneri breeding had higher birth, 3-month and 6-month weights compared with the $\mathrm{WL} \times \mathrm{B}$ cross which was composed of approximately $25 \%$ Local and $50 \%$ Bikaneri breeding. This trend was observed within each age of ram class during the year 1976. Combining the weights of the lambs born from 1 and 2-year old ewes, in 1976, WL $\times$ WLB cross breds were 4.7 per cent, 13.2 per cent and 10.8 per cent heavier than the $W L \times B$ cross breds 
at birth, 3 months and 6 months of age respectively. The results seem to indicate that the higher weights which were obtained in this analysis may be due to the slight increase in the Wiltshire Horn breeding component among the WL $\times$ WLB cross breds. In each cross bred group, lambs from 2-year old ewes were heavier than lambs from 1 year olds, reflecting a strong influence of the age of ewe. The year 1974 was a particularly good year for the WL $\times$ WLB cross breds as the body weights of all lambs were higher compared with lambs born in 1976. In fact, the lambs from 1 year old ewes in 1974 were heavier than lambs out of 2-year olds in 1976. Male lambs were heavier than females by about $0.14,0.69$ and $1.62 \mathrm{~kg}$ at birth, 3 months and 6 months respectively.

The weights of all cross bred sheep reported in this analysis were higher than for pure bred Bikaneri from the same farm as reported in an earlier paper by Goonewardene. ${ }^{8}$ However, the weights of the WL $\times \mathrm{B}$ and $\mathrm{WL} \times \mathrm{WLB}$ cross breds were lower than for Wiltshire Horn $\times$ Bikaneri cross breds from yearling ewes in their study. It could therefore be concluded that an improvement in weight was due to the influence of improved breeds such as the Wiltshire Horn in this program of cross breeding together with some maternal heterosis.

The assumed model 1 did not adequately adjust for year effects as the breeds and ages of rams did not overlap sufficiently across years.

Least squares means for Model 2 are shown in Table 4.

Table 4. Least squares means and standard errors for Model 2

\begin{tabular}{|c|c|c|c|c|c|}
\hline \multirow{2}{*}{$\begin{array}{l}\text { Breed of } \\
\text { ewe }\end{array}$} & \multirow{2}{*}{$\begin{array}{l}\text { Sex of } \\
\text { Lamb }\end{array}$} & \multirow{2}{*}{$n$} & \multicolumn{3}{|c|}{ Weight $(\mathrm{kg}) \pm S e$} \\
\hline & & & Birth & 3-month & 6-month \\
\hline $\mathrm{B}$ & $M \& F$ & 78 & $3.04 \div 0.05$ & $11.87+0.22$ & $17.37 \pm 0.26$ \\
\hline WLB & $M \& F$ & 110 & $3.26+0.05$ & $13.94 \div 0.18$ & $20.26+0.22$ \\
\hline$B \&$ WLB & $\mathrm{M}$ & 99 & $3.22 \pm 0.05$ & $13.24 \div 0.19$ & $19.72 \pm 0.23$ \\
\hline B \& WLB & $\mathrm{F}$ & 89 & $3.09+0.05$ & $12.57 \pm 0.20$ & $17.91 \pm 0.24$ \\
\hline
\end{tabular}

$M=$ Male

F - Female

The results show similar trends to the results of model 1 where the WL $\times$ WLB crosses were superior to $\mathrm{WL} \times \mathrm{B}$ cross breds at all ages. This may again be attributed to the advantage gained in having more Wiltshire Horn breeding among cross breds along with some maternal heterosis. Males were heavier than females at all ages; the differences were $0.13,0.67$ and $1.81 \mathrm{~kg}$ in favour of males, at birth, 3 months and 6 months of age respectively. 
The correlations between weight at different ages obtained from the two models are shown in table 5.

Table 5. Correlations between weights at different ages (Model 1 above diagonal Model 2 below diagonal)

\begin{tabular}{llll}
\hline & Birth & 3-month & 6-month \\
\hline Birth & - & $0.32^{* *}$ & $0.40^{* *}$ \\
3 months & $0.25^{*}$ & - & $0.76^{* *}$ \\
6 months & $0.36^{* *}$ & $0.67^{* *}$ & - \\
\hline
\end{tabular}

${ }^{* *} \mathrm{P}<0.01$

${ }^{*} \mathrm{P}<0.05$

Model 1 used 260 pairs of observations.

Model 2 used 188 pairs of observations.

The correlations between adjacent weights were always positive. The weight at 3 months was a better indicator of the weight at 6 months compared to birth weight. Furthermore, birth weight was not a very good indicator of 3-month weight as the correlations although positive in both models were lower than what was expected. The results of this study correspond with correlation between weights 1,?

\section{Conclusions}

The WL sires combined better with WLB ewes than with B ewes as the cross breds were heavier at birth, 3 months and 6 months. The superiority of the cross bred based on progeny performance may be attributed to the higher percentage of Wiltshire Horn breeding. Furthermore, the improvement in lamb weaning weights among the progeny of the WLB ewes may suggest that material heterosis is expressed among the cross bred ewes.

Under field conditions one could therefore advocate the use of cross bred ewes in order to achieve higher lamb weaning weights. The study also showed that the breed of ewe, age of ewe, and sex of lamb had a very significant effect on birth weight 3 -month and 6-month weight in model 1 . In model 2 however, sex of lamb was significant for all age groups but breed of ewe was significant only for 3 and 6-month weight. Selection for large weaning weights among lambs lead to higher weights at 6 months of age.

\section{Acknowledgements}

The authors wish to thank the Department of Animal Production and Health for allowing us to use the data for this study, Dr. D. Notter from Virginia Polytechnic 
and State University for his assistance in data analysis and Miss Irene Weerasinghe for typing this paper.

\section{References}

1. BAIZHUMANOV, A. (1973). Correlations among economic traits and their inheritance in cross bred sheep. Anim. Breed. Abs., $41:$ (3974): 453.

2. BUVANENDRAN, V. (1978). Sheep in Sri Lanka. World Animal Review $27: 13$.

3. BUVANENDRAN, V., JAINUDEEN, S. R. M., JAYASEKERA, S. B. \& DHARMASIRI G. A. (1970). Performance of two temperate breeds of sheep in Ceylon. Ceylon Vet. Jour. 18 (3); 70.

4. CHANG, T. S. \& RAE, A. L. (1961). Sources of variation in weaning weights of Rommey Marsh lambs. New Zeal. Jour. Agric. Res. 4 : (578).

5. DAFLAPURKAR, D. K., KATA PATAL, H. G. \& SINDHU, N. S. (1977). Birth weight studies in cross bred sheep. Anim. Breed Abs., $45:$ (252): 53.

6. FARID, A., MAKARECHIAN, M. \& SEFIDBAKHT, N. (1977). Cross breeding Iranian fat tailed sheep 1. Pre weaning growth performance of Karakul, Mehraban, Naeini and their reciprocal crosses. Animal Breed Abs., 45: (6576): 619.

7. GONZALES, J. E. (1972). Relationship between weights at birth, weaning and body weight of the dim, in sheep. Anim. Breed. Abs., 40: (1920): 301 .

8. GoOnewardene, L. A., Agalawatte, M. \& Jalatge, E. F. A. (1982). The effect of ram breed on the performance of cross bred sheep. Jour. Nat. Agric. Soc. of Ceylon, 19: 39.

9. HARVEY, W. R. (1975). Least squares analysis of data with unequal subclass numbers. USDA., ARS, $H-4$.

10. KASSAB, S. A. (1975). Some environmental factors affecting birth weight in Awassi sheep. Agric. Pakistan, 26: 207.

11. KORNAL, D., TRIPATHI, V. M. \& VASUDEVAN, B. (1976). Effects of sex, type of birth and month of birth on the birth weight of corriedale lambs. Ind. Vet. Jour., 53:526.

12. MATTER, H. E. (1973). Birth weight of Karkul lambs-reasons for its variance. Anim. Breed. Abs., $41:$ (4401) : 497.

13. RUTTLE, J. L. (1971). Influence of sex and type of birth on the performance of early weaned lambs. Jour. Anim. Sci., 32: 974.

14. SHIN, W. T., YOUM, W. H., PAIK, Y. K., CHEE, S. H. \& PARK, Y. I. (1977). Effect of certain environmental factors on birth and weaning weights on corriedale sheep. Anim. Breed Ahs., 45 : (1365) : 182.

15. STEEL, G. \& TORRIE, J. H..(1960) Principles and Procedures of Statistics. McGrawhill Book Co., Inc. N.Y.

16. VAN DER POOTEN, E. (1972). Two years with Finn Sheep in Ceylon. Animal production and Health Bull. 6 : (2): 73. 